\title{
Students' Home Activities and Academic Performance in Economics in Senior Secondary School II in Isoko South Local Government Area of Delta State
}

\author{
Kingsley Akarowhe* \\ Department of Educational Foundations, University of Uyo, Nigeria
}

*Corresponding author: Kingsley Akarowhe, Department of Educational Foundations, Guidance and Counselling, Faculty of Education, University of Uyo, Uyo Akwa Ibom State, Nigeria.

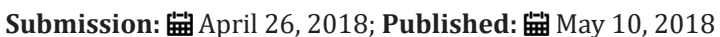

\begin{abstract}
This study investigated the influence of students' home activities on their academic performance in Economics in senior secondary school II in Isoko South Local Government Area of Delta State. Three research questions were answered in the study and three null hypotheses were tested at .05 level of significance. The population of the study consisted of 1,130 senior secondary school II in Isoko South Local Government Area of Delta State. A sample size of 113 students was adopted; this was 10 percent of the entire population. A 21 structured questionnaire was used to elicit responses from the respondents (students). The questionnaire was face-validated by experts in Faculty of Education, University of Uyo. Cronbach's Alpha Technique was used in determining the reliability of the instrument and a correlation coefficient of 0.76 was obtained. Mean with standard deviation was used to answer the three research questions. The independent t-test statistic was used to test the three null hypotheses. The findings of the study reveal that home chore activities such as peer group, social network and television watching has a high and significant influence on students' academic performance in Economics in senior secondary school II in Isoko South Local Government Area of Delta State. Based on the findings, it is recommended among other things that Delta State Government should regulate the television programme content in other to inculcate high insight in the student in the domains of learning (cognitive domain, psychomotor domain and affective domain).
\end{abstract}

Keywords: Economics; Home activities; Peer group; Social network; Television watching

\section{Introduction}

Economics is one of the subjects prescribed by the Federal Ministry of Education in the National Policy of Education (NPE) to be offered as a non-vocational course by senior secondary school students. It is a compulsory subject for social science students. According to [1], economics is a social science which study human behaviour, as a relationship between ends and scarce means which have alternative uses. As one of the compulsory subjects in social science, students are expected to have a satisfactory academic performance in it, due to the fact that it will equip a student on effective and efficient management of limited resources, in making choices in the world of limited resources and maintaining his/ her self with the basic needs of life through acquisition of saleable entrepreneur skills.

Academic performance can be tested by the teachers through obtaining of learning objective from the cognitive, psychomotor and affective domain of learning. Students' home activities may have a pace in their academic performance. Home activities vary from individual students to another, given their parental economic, educational, religious status. Home activities are wide range of work an individual do intrinsically or extrinsically for personal pleasure or to satisfy other people's mandate. Students' home activities encompasses all after-school-involvement which students participate in at home. These activities include watching of video and television, cooking, involvement in peer group discussion, chatting on social network platforms. Such activities may exert some level of influence on students' academic performance due to the fact that, after school hour student spend most of their time at home which range between 6-11 hours. In line with the purpose of this study the researcher vividly investigate students' home activities such as peer group activities, social network activities and television watching as it influences their academic performance.

Peer group is one of the important agents of socialization after the family. Peer group is the first social group outside the home which the adolescent attempts to gain acceptance from in the school. Peer group being the first social group outside the family 
tends to exert either a positive or negative influence on students. The tendency of individuals to affiliate with others, who share similar attributes in an ever changing social setting of their interest, does not only influences their disposition but may likely influence their learning abilities. In light $[2,3]$ found that peer effects student outcomes. This may likely be due to the fact that as children develop into adolescents, they spend an increasing amount of time with their peers compared to their parents and other adults. Peer group can exert a positive influence on a student being that, when peer group code of conduct are tailored for high academic achievement a student who intend to belong to such group will in the long-run perform better in school in their academics.

Social network is a web base platform that tends to bridge communication lags between and expected users. According to [4] define social network sites as web-based services that allow individuals to construct profiles, display user connections, and search and traverse within that list of connections. Information communicated on the social network ranges from personal to national issues which may influence the users in their cognitive, psychomotor and affective domain of learning. Social network is a platform which often regulates the behaviour of a student, being that information passed to a particular student may have a positive or negative effect on him/her. According to [5], social network websites grab attention of the students and then diverts it towards non-educational and inappropriate actions including useless chatting. Social networking media has gained considerable attention as a factor affecting students' academic performance $[6,7]$. Greater percent of student tends to surface on social network platforms than being committed to their academic works after school.

Television is an electronic device that passes a wide range of information over a long range to an expected audience(s). Through television watching, students' are informed about a particular situation/scenario within their immediate environment and the society at large. Information communicated to the student(s) through television may affecthis academics and adjustmentat school. Television watching as a learning process can promote general learning as well as pre-school children's academic performance either negatively or positively. According to [1] television watching has a negative effect on both academic achievement and languages acquisition of pre-school children. This may be due to the fact, most television programmes watched by student make them to learn incorrect English; and similarly student tends to spend much time in watching television rather than studying their books. Watching educational television programs may enhance school readiness and academic performance [8]. It is in relation with the forgoing the researcher investigated students' home activities on their academic performance in Economics in senior secondary school II in Isoko south local government area of Delta State.

\section{Statement of the problem}

In the last decades, students are often seen at home engaging in gainful activities such as studying their Economics textbooks; reading their Economics note; involving in discussions of National
Economic issues with peer groups that will enhance their academic performances. Their home activities were guided to improve on their performance and there were no distractions like what is present today. The recent Senior Secondary Certificate Examination (SSCE) and West African Examination Council (WAEC) results of students who failed Economics in Isoko South Local Government Area of Delta State was worrisome, this pitiable condition has led to the shift of blame among different stakeholders in the education sector. This may likely due to the fact that, students nowadays do not use their off-school hours at home for gainful activities which will propel them for better performance in their academics. They often participate in activities such as peer group gathering, social networking, television watching and the like of others. Students spent little or no time on their academics work at home due to these activities. In most cases, students do not even take their assignments seriously. This perplexing situation has continued without solution in sight, this provided the fertile ground for the researcher to determine students' home activities and academic performance in Economics in senior secondary school II in Isoko south local government area of Delta State.

\section{Purpose of the study}

The major purpose of the study was to determine the influence of students' home activities on their academic performance in Economics in senior secondary schools II in Isoko South Local Government Area of Delta State. Specifically, the study sought to determine.

A. Peer group activities influence on students' academic performance in Economics.

B. Social network activities influence on students' academic performance in Economics.

C. Television watching activities influence on students' academic performance in Economics.

\section{Research questions}

To guide the study the following research question were asked. What is the influence of

a. Peer group activities on students' academic performance in Economics in senior secondary school II in Isoko South Local Government Area of Delta State?

b. Social network activities on students' academic performance in Economics in senior secondary school II in Isoko South Local Government Area of Delta State?

c. Television watching on students' academic performance in Economics in senior secondary school II in Isoko South Local Government Area of Delta State?

\section{Null hypotheses}

In line with the purpose of the study, the following hypotheses were tested in the study at .05 level of significance

I. $\mathrm{H}_{\mathrm{o} 1}$ : Peer group activities do not significantly influence academic performance in Economics in senior secondary school II in Isoko South Local Government in Delta State. 
II. $\mathrm{H}_{\mathrm{o} 2}$ : Social network activities do not significantly influence academic performance in Economics in senior secondary school II in Isoko South Local Government in Delta State.

III. $\mathrm{H}_{03}$ : Television watching activities do not significantly influence academic performance in Economics in senior secondary school II in Isoko South Local Government in Delta State.

\section{Research Methods}

The descriptive survey research design was adopted for the study. The study was conducted in Isoko South Local Government Area of Delta State. The population of the study comprised 1,130 students of Economics in senior secondary school, in Isoko South Local Government Area of Delta State. A sample of 113 teachers was adopted for the study, which was 10 percent of the entire population. A structured questionnaire titled: 'Students' Home Activities and Academic Performance in Economics Questionnaire (SHAAPEQ)' in Isoko South Local Government Area was used to elicit responses from the respondents for the study. The questionnaire was designed based on the dependent and independent variables in the study. The questionnaire was divided into two sections (A and B). Section 'A' contained the personal data of the respondents. Section ' $\mathrm{B}$ ' contained the statements on the variables grouped into three clusters (1-3) namely: peer group activities, social network activities and television watching activities. The response options were: Very High Influence (VHI)-4 points, High Influence (HI)-3 points, Moderate Influence (MI)-2 points and Little Influence (LI)-1 point. The instrument was subjected to face-validation by validators in the Faculty of Education, University of Uyo. The internal consistency of the instrument was determined using Cronbach's alpha reliability method and this yielded a reliability coefficient of .76. The questionnaire was administered on the respondents by the researcher and a total of 113 copies were returned. Mean and standard deviation was used to answer the three research questions, while the independent t-test was used to test the three null hypotheses at .05 level of significance. The influence of particular home activities on students' academic performance was determined using real limit as follows: Very High Influence (VHI)3.50-4.00, High Influence (HI)-2.50-3.49, Moderate Influence (MI)1.50-2.49 and Little Influence (LI)-0.5-1.49. This real limit was applied to research questions. On the other hand, in testing the null Hypotheses at .05 level of significance, $H_{0}$ was rejected in favour of $\mathrm{H}_{1}$ when the computed statistical value exceeds or equal to the Table value, otherwise $\mathrm{H}_{\mathrm{o}}$ was retained.

\section{Results}

\section{Answering of research questions}

Research questions 1: What is influence of peer group activities on students' academic performance in Economics in senior secondary school II in Isoko South Local Government Area of Delta State? The result presented in Table 1 revealed that the items on peer group activities have a grand mean of 3.35. This indicates that, peer group activities have a high influence on students' academic performance in Economics in senior secondary school II in Isoko South Local Government Area of Delta State. All the items have their mean scores above the cut-off point of 2.00. The item on, 'My friends in the neighbourhood always encourage me to study hard', has the highest mean score $(=3.49)$. The remaining items have their means ranging between 3.11-3.48. The Table also shows that the standard deviation of the items fall within the range of $0.67-0.82$, this indicates that the respondents were not divergent in their responses.

Table 1: Mean responses of the respondents on the influence of peer group activities on students academic performance.

\begin{tabular}{|c|c|c|c|c|}
\hline $\mathbf{S} / \mathbf{N}$ & Items on Peer Group Activities & $\overline{\mathrm{X}}$ & SD & Remark \\
\hline 1 & I do follow my friends to parties after schools & 3.4 & 0.68 & HI \\
\hline 2 & I join my friends in their violent behaviours in the locality & 3.48 & 0.69 & $\mathrm{HI}$ \\
\hline 3 & My friends in the neighbourhood encourages me to take hard drugs & 3.35 & 0.76 & $\mathrm{HI}$ \\
\hline 4 & I often discuss what was taught in the school with peers at home & 3.2 & 0.71 & $\mathrm{HI}$ \\
\hline 5 & My friends in the neighbourhood always encourage me to study hard & 3.49 & 0.6 & $\mathrm{HI}$ \\
\hline 6 & I hardly read my books at home because my friends in the neighbourhood do not read theirs & 3.11 & 0.82 & HI \\
\hline 7 & My friends are majorly school dropouts & 3.41 & 0.67 & HI \\
\hline \multicolumn{2}{|r|}{ Grand Mean } & 3.35 & 0.7 & HI \\
\hline
\end{tabular}

VHI: Very High Influence; HI: High Influence; MI: Moderate Influence; LI: Little Influence

Research questions 2: What is influence of social network activities on students' academic performance in Economics in senior secondary school II in Isoko South Local Government Area of Delta State? The result presented in Table 2 revealed that the items on social network activities have a grand mean of 3.30. This indicates that, social network activities have a high influence on students' academic performance in Economics in senior secondary school II in Isoko South Local Government Area of Delta State. All the items have their mean scores above the cut-off point of 2.00 . The item on, 'I spend more than five hours on Facebook every week', has the highest mean score $(\bar{x}=3.73)$. The remaining items have their means ranging between 2.89-3.50. The Table also shows that the standard deviation of the items fall within the range of 0.22 0.96 , this indicates that the respondents were convergent in their responses. 
Table 2: Mean responses of the respondents on the influence of social network activities on students academic performance.

\begin{tabular}{|c|c|c|c|c|}
\hline $\mathbf{S} / \mathbf{N}$ & Items on Social Network Activities & $\overline{\mathrm{X}}$ & SD & Remark \\
\hline 1 & I hardly read my books because I am always chatting on face-book & 3.17 & 0.61 & $\mathrm{HI}$ \\
\hline 2 & I often sleep in the classroom because I always chat online in the midnight & 2.99 & 0.22 & HI \\
\hline 3 & I loss concentration in class because I often mediate on my recent conversation with friends online & 3.45 & 1.77 & $\mathrm{HI}$ \\
\hline 4 & I neglect my home work in order to chat with friends online & 3.43 & 0.59 & $\mathrm{HI}$ \\
\hline 5 & I always discuss academic issues when chatting online with friends & 3.5 & 2.13 & HI \\
\hline 6 & I spend more than five hours on Facebook every week & 3.73 & 0.64 & $\mathrm{HI}$ \\
\hline 7 & I do chat while reading at the same time & 2.89 & 0.96 & $\mathrm{HI}$ \\
\hline \multicolumn{2}{|r|}{ Grand Mean } & 3.3 & 0.99 & $\mathrm{HI}$ \\
\hline
\end{tabular}

VHI: Very High Influence; HI: High Influence; MI: Moderate Influence; LI: Little Influence

Research questions 3: What is influence of television watching activities on students' academic performance in Economics in senior secondary school II in Isoko South Local Government Area of Delta State? The result presented in Table 3 revealed that the items television watching activities have a grand mean of 3.30. This indicates that, television watching activities have a high influence on students' academic performance in Economics in senior secondary school II in Isoko South Local Government Area of Delta Table 3: Mean responses of the respondents on the influence of television watching activities on students academic performance.

\begin{tabular}{|c|c|c|c|c|}
\hline $\mathbf{S} / \mathbf{N}$ & Items on Television Watching Activities & $\overline{\mathrm{X}}$ & SD & Remark \\
\hline 1 & I hardly read at night because I often watch television & 3.41 & 0.67 & HI \\
\hline 2 & I often abandon my reading because of television programmes & 3.2 & 0.74 & HI \\
\hline 3 & I always watch television programme that are related to my subjects in the school & 2.01 & 2.04 & MI \\
\hline 4 & I always wake up late to school because at night I watch television & 3.48 & 1.68 & HI \\
\hline 5 & I often spend more time in watching television & 3.3 & 0.41 & HI \\
\hline 6 & I can watch television while reading at the same time & 3.28 & 0.74 & HI \\
\hline 7 & I cannot follow up my reading time table because of television watching & 2.51 & 1.68 & HI \\
\hline \multicolumn{2}{|r|}{ Grand Mean } & 3.02 & 1.14 & HI \\
\hline
\end{tabular}

VHI: Very High Influence; HI: High Influence; MI: Moderate Influence; LI: Little Influence

\section{Testing of the Null Hypotheses}

\section{Hypothesis 1}

Peer group activities do not significantly influence students' academic performance in Economics in senior secondary school II in Isoko South Local Government in Delta State. The analysis in Table 4 produced a t-value of 3.83. When compared with the critical $\mathrm{t}$-value of 1.96 at .05 confidence level with 111 degree of freedom, it was found to be greater. Based on this finding, the null hypothesis was rejected and the alternative hypothesis which states that, peer group activities significantly influence students' academic performance in Economics in senior secondary school II in Isoko South Local Government in Delta State is retained.

Table 4: Summary of independent t-test analysis on the influence of peer group activities on students' academic performance.

\begin{tabular}{|c|c|c|c|c|}
\hline Gender & $\mathbf{N}$ & Mean & SD & t-value \\
\hline Male & 70 & 15.19 & 2.55 & \multirow{2}{*}{3.83} \\
\hline Female & 43 & 17.16 & 2.84 & \\
\hline
\end{tabular}

$\mathrm{P}<.05 ; \mathrm{df}=111 ;$ Crit. $\mathrm{t}=1.96$
State. All the items have their mean scores above the cut-off point of 2.00. The item on, 'I always wake up late to school because at night I watch television', has the highest mean score $(\bar{X}=3.48)$. The remaining items have their means ranging between 2.01-3.41. The Table also shows that the standard deviation of the items fall within the range of $0.41-2.04$, this indicates that the respondents were convergent in their responses.

\section{Hypothesis 2}

Social network activities do not significantly influence students' academic performance in Economics in senior secondary school II in Isoko South Local Government in Delta State. The analysis in Table 5 produced a t-value of 2.98 . When compared to the critical t-value of 1.96 at .05 confidence level with 111 degree of freedom, it was found to be greater. Based on this finding, the null hypothesis was rejected and the alternative hypothesis which states that, social network activities significantly influence students' academic performance in Economics in senior secondary school II in Isoko South Local Government in Delta State is retained.

Table 5: Summary of independent t-test analysis on the influence of social network activities on students' academic performance.

\begin{tabular}{|c|c|c|c|c|}
\hline Gender & $\mathbf{N}$ & Mean & SD & t-value \\
\hline Male & 70 & 13.03 & 4.32 & \multirow{2}{*}{2.98} \\
\hline Female & 43 & 15.6 & 4.56 & \\
\hline
\end{tabular}

$\mathrm{P}<.05 ; \mathrm{df}=111 ;$ Crit. $\mathrm{t}=1.96$ 


\section{Hypothesis 3}

Television watching activities does not significantly influence students' academic performance in Economics in senior secondary school II in Isoko South Local Government in Delta State. The analysis in Table 6 produced a t-value of 2.79. When compared to the critical t-value of 1.96 at .05 confidence level with 111 degree of freedom, it was found to be greater. Based on this finding, the null hypothesis was rejected and the alternative hypothesis which states that, television watching activities significantly influence students' academic performance in Economics in senior secondary school II in Isoko South Local Government in Delta State is retained.

Table 6: Summary of independent t-test analysis on the influence of television watching activities on students' academic performance.

\begin{tabular}{|c|c|c|c|c|}
\hline Gender & N & Mean & SD & t-value \\
\hline Male & 70 & 14.93 & 3.95 & \multirow{2}{*}{2.79} \\
\hline Female & 43 & 16.7 & 1.67 & \\
\hline
\end{tabular}

$\mathrm{P}<.05 ; \mathrm{df}=111$; Crit. $\mathrm{t}=1.96$

\section{Findings of the Study}

The following findings emerge from the study conducted on students' home activities and academic performance in senior secondary school II in Isoko south local government area of Delta State.

a) Peer group activities have a high influence on students' academic performance in Economics.

b) Social network activities have a high influence on students academic performance in Economics.

c) Television watching activities have a high influence on students' academic performance in Economics.

d) Peer group activities significantly influence academic performance in Economics.

e) Social network activities significantly influence academic performance in Economics.

f) Television watching activities significantly influence academic performance in Economics.

\section{Discussion of Findings}

The findings of this study are discussed based on the specific purposes of the study. The result of research question one indicated that peer group activities have a high influence on students' academic performance in Economics and that peer group activities significantly influence academic performance in Economics in senior secondary school II in Isoko South Local Government in Delta State. This finding is in line with the earlier finding of [4] who found that peer effects student outcomes. This result of this finding may be due to that fact peer group tends to reshape student behaviour to their study. The result of research question two presented showed that social network activities have a high influence on students' academic performance in Economics and that social network activities significantly influence academic performance in Economics in senior secondary school II in Isoko South Local Government in Delta State. This finding was in line with the finding of [6] who found that social network websites grab attention of the students and then diverts it towards noneducational and inappropriate actions including useless chatting. Similarly, this finding was in consonance with the findings of $[9,7]$ who found that social networking media has gained considerable attention as a factor affecting students' academic performance. The finding pinpoint the fact that as more time is spent by student on social platforms the more they tend to reduce the hour they devout for their study, which often leads to declining performance.

The result that provided answer to research question three presented showed that television watching activities have a high influence on students' academic performance in Economics and that television watching activities significantly influence academic performance in Economics in senior secondary school II in Isoko South Local Government in Delta State. This finding contradicted the finding of [2] who found that television watching has a negative effect on both academic achievement and languages acquisition of pre-school children. Although the finding was in consonance with the findings of [1] who found that watching educational television programs may enhance school readiness and academic performance. The researcher wish to observe that, this finding may be due to fact that as student get glue to the television set their academic performance will witness a regressive tendency in the long-run.

\section{Conclusion}

Home activities such as peer group, social network, television watching has a high and significant influence on academic performance in Economics in senior secondary school II in Isoko South Local Government in Delta State.

\section{Recommendations}

Based on the findings of this study, the following recommendations are made:

A. Delta State Government should regulate the television programme content in other to inculcate high insight in the student in the domains of learning (cognitive domain, psychomotor domain and affective domain).

B. Parents should institutionalize rules at home to govern the conduct of their children in the use of social media devices. This will assist them to pay more attention in their study and rest.

C. Parents should monitor, control and know the types of friend their children keeps. This will ensure that their useful habit will not be spoiled by bad association, given the fact that; associating with student who performances in academics is poor will induces one to also have poor performance, similarly associating with student with excellence performance will make one to perform better at school academically. 


\section{References}

1. Robbin L (1935) An essay on the nature and significance of economics science. Macmillan, London, UK.

2. Kang C (2007) Classroom peer effects and academic achievement: Quasirandomization evidence from South Korea. Journal of Urban Economics 61(3): 458-495.

3. Duflo E, Dupas P, Kremer M (2008) Peer effects and the impact of tracking: Evidence from a randomized evaluation in Kenya. NBER Working Paper 14475, National Bureau of Economic Research, Cambridge, MA, USA.

4. Boyd D, Ellison N (2007) Social network sites: Definition, history, and scholarship. Journal of Computer-Mediated Communication 13(1): 1-11.

5. Kuppuswamy S, Narayan P (2010) The impact of social networking websites on the education of youth. International Journal of Virtual Communities and Social Networking 2(1): 67-79.
6. Paul JA, Hope MB, Cochran JD (2012) Effect of online social networking on student academic performance. Computers in Human Behavior 28(6): 2117-2127.

7. Rouis S, Limayem M, Salehi SE (2011) Impact of Facebook usage on students' academic achievement: Role of self-regulation and trust. Journal of Research in Educational Psychology 9(3): 961-994.

8. Avosa AA, Zadock OM, Michael 00, Benson CO, Joel O (2014) Effects of television on academic performance and languages acquisition of preschool children. International Journal of Education and Research 2(11): 493-502.

9. Anderson N, Wright J (2001) Attention comprehension and educational influences of television. Sage Publication, London, UK. (c) (i) Creative Commons Attribution 4.0

For possible submissions Click Here

\section{Submit Article}

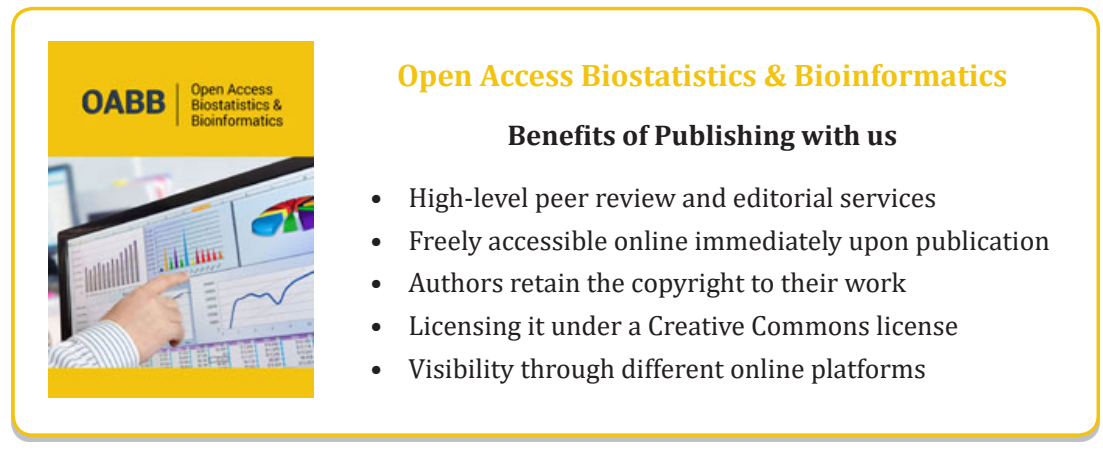

